\title{
SIEMENPERUSRUNKOJEN VAIKUTUS OMENAPUIDEN SATOVAIHTELUIHIN
}

\author{
JAAKKO SÄKÖ \\ Maatalouskoelaitoksen puntarhaosasto, Piikkiö
}

Saapunut 10. 9. 1953.

Kolme vuosikymmentä sitten julkaistiin ensimmäiset tulokset East Malling'in tutkimuslaitoksessa, Englannissa, järjestetyistä omenapuiden perusrunkokokeista. Näissä tutkimuksissa sekä myöhemmin julkaistuissa (3 ja 4) selvitettiin sitä erilaista vaikutusta, mikä tietyillä klooniperusrungoilla on niille vartettujen jalolajikkeiden ominaisuuksiin, kuten mm. puiden kasvuun, kukkasilmujen muodostumisen runsauteen sekä aikaissatoisuuteen ja sadon määrään. Tutkittujen klooniperusrunkotyyppien erilainen vaikutus osoittautui siksi selväksi, että kyseessä olevat perusrungot voitiin jakaa neljään ryhmään, kääpiöiviin, puolikääpiöiviin, voimakaskasvuisiin ja erittäin voimakaskasvuisiin. Tutkimuksissa todettiin kuitenkin kasvunvoimakkuuden olevan suhteellista eri lajikkeilla. Samalla tähdennettiin myös sitä, että siemenperusrungot heterozygoottisuutensa vuoksi aiheuttavat huomattavia vaihteluja niillä kasvaville omenapuille. Jotta tietyn omenapuulajikkeen eri yksilöiden kasvu ja satojen suuruus y.m. ominaisuudet muodostuisivat samanlaisiksi, pidettiin välttämättömänä siirtyä kokonaan perinnö!lisesti yhdenmukaisten klooniperusrunkojen käyttöön ja hylätä peruasultaan teoreettisestı epäyhtenäiset siemenperusrungot.

Edellä mainittujen tutkimustulosten tultua tunnetuksi yleistyi Malling- eli M-klooniperusrunkojen käyttö nopeasti muissakin maissa. Varsinkin kääpiöivät ja puolikääpiöivät tyypit saavuttivat erityistä suosiota, koska näille perusrungoille vartetut puut tarvitsevat hillityn kasvunsa vuoksi pienemmän kasvualan. Lisäksi pidettiin tällaisille perusrungoille vartettujen omenapuiden aikaissatoisuutta huomionarvoisena ominaisuutena.

Myöhemmin on kuitenkin käynyt selville, etteivät M-klooniperusrungot ole käytännössä aikaansaaneet selvää puiden yhdenmukaista kasvua ja kehitystä, vaan päinvastoin voidaan klooniperusrunkojakin käytettäessä löytää varsin eriarvoisia puusyksilöitä. Toisaalta taas siemenperusrungoille vartetut puut eivät useinkaan ole osoittaneet sen suurempia yksilöiden välisiä vaihteluja kuin edellä mainitut. Niinpä saksalainen Kemmer (5) on tullut siihen käsitykseen, että myös peruasultaan 
samanarvoisilla klooniperusrungoilla kasvaneet puut saattavat olla hyvin vaihtelevia. Tämä johtuu siitä, että hedelmäpuu on suurestı riippuvainen sen saamasta hoidosta ja kasvupaikalla vallitsevista olosuhteista. Kemmer korostaa, ettei mikään perusrunko kykene poistamaan niitä vaihteluja, joita tällaiset ulkoiset tekijät aiheuttavat. Näinollen on kyseenalaista onko lajikkeen yhdenmukaisuus käytännössä sen suurempi klooni- kuin siemenperusrungoillakaan. Siemenperusrunkoihin nähden on kuitenkin olemassa tärkeä ero siinä, ovatko perusrungot diploidisten tai triploidisten lajikkeiden siementaimia. Jälkimmäisten siementaimien peruasun vaihtelu on erittäin suuri. Niistä kehittyneet perusrungot ovat epäyhtenäisiä ja yleensä heikkokasvuisia. Sensijaan diploidisten omenapuulajikkeiden siemenistä kasvatetut perusrungot ovat huomattavasti yhdenmukaisempia. Kemmerin (5) tutkimista 7 diploidisen omenapuulajikkeen siementaimista oli $64.0-95.6 \%$ kasvultaan tasaista, ensiluokkaista perusrunkoaineistoa, mutta taas 7 triploidisen lajikkeen siementaimista oli vain $5.1-16.3 \%$ kunnollista.

Yhdysvalloissa ovat kauppahedelmätarhojen omenapuut pääasiassa vartettu tai silmikoitu siemenperusrungoille. Vaikka perusrunkojen kasvatukseen käytetty siemen on saattanut olla peräisin useista lajikkeista, ovat näille rungoille jalonnetut omenapuut kasvaneet yllättävän samantapaisesti. Siellä järjestetyissä omenapuiden perusrunkokokeissa ei alkuperältään ranskalaisilla siemenperusrungoilla kasvavien puiden vaihtelu ole ollut sanottavasti suurempi kuin klooniperusrungoillakaan (1).

Southwickn ja SHown tutkimuksissa on ilmennyt, että M-klooniperusrungoille vartettujen puiden vaihtelut ovat lisääntyneet puiden vanhetessa. Heidän käsityksensä mukaan on omenapuiden yhdenmukaisuuteen pyrittäessä varsin vähän hyötyä klooniperusrunkojen käytöstä.

UpPShalln (12) mukaan eivät M-XVI, I ja II kloonirungoilla olevat omenapuut ole Vineland'issa (Ontario) osoittaneet kasvussa eikä sadossakaan sen suurempaa yhdenmukaisuutta kuin ranskalaisille siemenperusrungoille vartetut vertauspuut.

Summerland'issa (British Columbia) järjestetyissä omenapuiden perusrunkokokeissa ovat Mc Intosh- ja Red Delicious-lajikkeet antaneet 10 vuotiaina yhtäsuuria satoja siemenperusrungoilla kuin klooniperusrungoillakin. Sekä siemenettä klooniperusrunkopuut ovat tässä kokeessa olleet erittäin yhdenmukaisia (9).

Suomessa ovat siemenperusrungoille vartetut puut omanneet paremman ilmastollisen kestävyyden ja osoittautuneet vähemmän alttiiksi ympäristötekijäin vaikutuksille kuin M-klooniperusrungoille vartetut puut. Kartiomenapuiden perusrunkokokeessa Godby'ssä, missä perusrunkoina olivat M IX ja M II klooniperusrungot, ja jossa puiden leikkaus ja muu hoito oli järjestetty mahdollisimman yhdenmukaiseksi, osoittivat puiden kokonaissadot ensi kymmenvuotisjaksolla varsin suurta vaihtelua. Niinpä Melba-lajikkeella sato vaihteli $3-7$ kertaisesti (8).

Meurman (6 ja 7 ) on tutkimuksissaan selvittänyt eräiden siemenperusrungoille vartettujen omenapuulajikkeiden satoisuutta. Näiden puiden satotuloksia tarkastellessaan hän esittää, että, vaikka siemenperusrungoilla olevien puiden sadot vuosittain vaihtelevatkin eri yksilöillä, eivät saman lajikkeen kokonaisssadot osorta pitemmän ajanjakson kuluttua tarkasteltaessa suuria eroja. 
Taulukko 1. Neljän siemenperusrungolle vartetun Sokeri Miron-puun vuosittaiset satotulokset v. 1937-1952. Puut istutettu v. 1934 keväällä.

Table 1. Annual crops of four Sugar-Miron apple trees from 1937 to 1952. The trees were planted in spring 1934.

Puun n:o No. of tree

\begin{tabular}{|c|c|c|c|c|c|}
\hline $\begin{array}{l}\text { Vuosi } \\
\text { Year }\end{array}$ & $\begin{array}{l}\text { VI:3 } \\
\mathrm{kg}\end{array}$ & $\begin{array}{c}\mathrm{VI}: 4 \\
\mathrm{~kg}\end{array}$ & $\begin{array}{c}\text { VII:3 } \\
\text { kg }\end{array}$ & $\begin{array}{l}\text { VII:4 } \\
\text { kg }\end{array}$ & \\
\hline 1937 & 1.9 & 2.0 & 1.4 & 0.4 & \\
\hline 1938 & 2.0 & 0.1 & 1.1 & 0.6 & \\
\hline 1939 & 0.9 & 4.3 & 1.1 & 1.4 & \\
\hline Yht. & & & & & 6 vuotta istutuksesta \\
\hline $1937-39$ & 4.8 & 6.4 & 3.6 & 2.4 & \\
\hline Total & & & & & 6 years from planting \\
\hline 1940 & 6.0 & 1.0 & 2.6 & 0.5 & \\
\hline 1941 & 1.3 & 2.9 & 1.2 & 0.9 & \\
\hline 1942 & 13.8 & 15.9 & 20.4 & 17.2 & \\
\hline 1943 & 14.1 & 28.3 & 12.0 & - & \\
\hline 1944 & 9.3 & 5.8 & 20.6 & 27.3 & \\
\hline Yht. & & & & & 11 vuotta istutuksesta \\
\hline $1937-44$ & 49.3 & 60.2 & 60.4 & 48.3 & \\
\hline Total & & & & & 11 years from planting \\
\hline 1945 & 16.3 & 28.7 & 25.7 & 36.6 & \\
\hline 1946 & 42.5 & 36.8 & 71.1 & 69.2 & \\
\hline 1947 & 0.7 & 45.0 & 0.2 & 4.1 & \\
\hline 1948 & 54.0 & 18.1 & 68.6 & 88.4 & \\
\hline 1949 & 44.3 & 127.7 & 17.9 & - & \\
\hline Yht. & & & & & 16 vuotta istutuksesta \\
\hline $1937-49$ & 207.1 & 316.4 & 243.9 & 246.6 & \\
\hline Total & & & & & 16 years from planting \\
\hline 1950 & 60.4 & - & 71.3 & 91.6 & \\
\hline 1951 & 25.9 & 103.2 & 0.7 & 2.7 & \\
\hline 1952 & 97.0 & 1.5 & 90.3 & 109.4 & \\
\hline Yht. & & & & & 19 vuotta istutuksesta \\
\hline $1937-52$ & 390.4 & 421.3 & 406.2 & 450.3 & \\
\hline Total & & & & & 19 years from planting \\
\hline
\end{tabular}

Seuraavassa esitetään osittain jatkoa MEurmann tutkimuksille ( 6 ja 7 ) seuraamalla edellä mainittujen siemenperusrunkopuiden satoja myöhempien vuosien aikana.

\section{Koeolosuhteet ja satotulosten esittely}

Vuonna 1934 perustettiin Maatalouskoelaitoksen puutarhaosastolle kesäomenain lajikekoe, jossa oli mukana 5 lajiketta, kutakin 16 puuta. Koe sijoitettiin savi- 

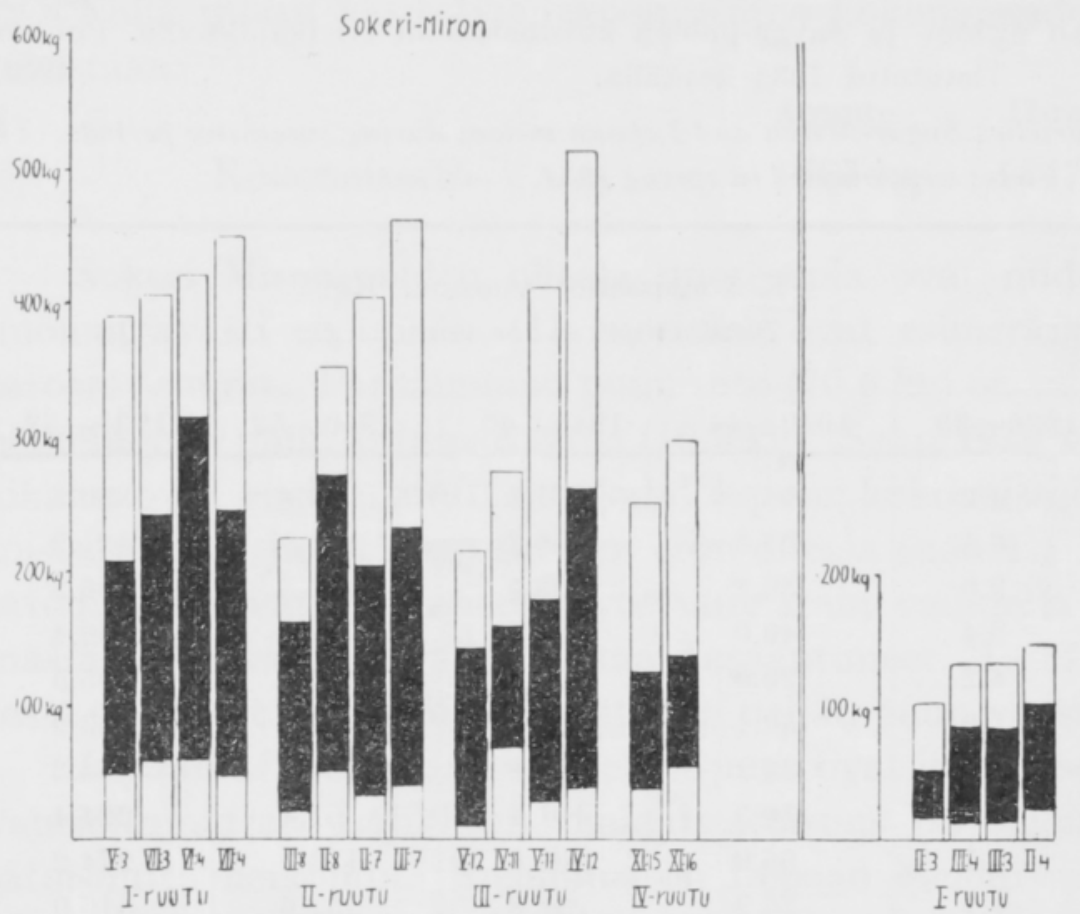

Lepaan meioni

Piirros 1 ja 2. Siemenperusrungoille vartettujen Sokeri-Miron- ja Lepaan melonipuiden kokonaissadot v. 1934 -52. Pylvään vaalea alaosa esittää satoa v. 1934 44, tumma keskiosa satoa v. 1945 — 49 ja pylvään vaalea huippu satoa viimeiseltä kolmivuotiskaudelta v. $1950-52$. Puut on istutettu v. 1934 keväällä.

Figures 1 and 2. Total crops of the apple varieties Sugar-Miron and Lepaan meloni upon seedling stocks during the years 1934-52. In the diagram the lower parts represent the crops during the years 1934-44, the dark middle part those of 1945-49 and the uppermost parts the crops during the last three-year period.

maalle. Kaikki puut oli vartettu tietyn saman lajikkeen siemenistä kasvatetuille perusrungoille. Puut istutettiin siten, että neljä saman lajikkeen puuta muodosti koeruudun ja istutus etäisyydeksi tuli 5 kertaa $4 \mathrm{~m}$. Erittäin ankarat pakkastalvet 1939-1942 aiheuttivat koepuille pahoja vaurioita. Parhaiten säilyivät näiden talvien yli lajikkeet Lepaan Melonı, Sokeri Miron ja Snygg. Täysin vaurioitumatta selvisivät Lepaan Meloni-puut; Sokeri Miron-puista kuoli ainoastaan yksi. Puut on kasvatettu runkojohtoisiksi ja ovat ne istutuksesta lähtien saaneet täysin yhdenmukaisen leikkauksen, lannoituksen ja muun hoidon.

Puiden kokonaissadot on esitetty piirroksissa 1-3 pylväinä. Jokainen pylväs esittää yhden puun kokonaissatoa 19 vuoden kuluttua istutuksesta lukien. Pylväiden vaalea alaosa esittää kokonaissatoja puiden ollessa 11-vuotiaita, tumma keskusta satoa seuraavalta 5-vuotiskaudelta (12-16 vuotta) ja pylvään vaalea huippu viimeisen kolmivuotiskauden satoa. Satotulokset on piirroksissa kuvattu koeruuduttain. Satotulokset käyvät myös ilmi oheen liitetystä taulukosta 2.

Snygg-lajikkeen kohdalla ei puiden satotuloksia ole seurattu pitemmälle kuin 15 vuotta istutuksesta lähtien, koska useimmat ko. kokeen Snygg-puut ovat aivan viime vuosina kuolleet. Puiden kuoleminen ei ole johtunut kuitenkaan heikosta ilmastollisesta kestävyydestä — Snygg on eräitä kestävimpiä lajikkeitamme —, vaan siitä syystä, että lajikkeen puuaines on erittäin haurasta ja repeilylle altista. Tästä johtuen Snygg-puut alkavat vanhetessa nopeasti ränsistyä. 
Taulukko 2. Sokeri-Miron-, Lepaan meloni- ja Snygg-puiden kokonaissadot eri ikäjaksoina. Puut on istutettu 1934 keväällä.

Table 2. Total crops of the apple varieties Sugar-Miron and Lepaan meloni during successive periods. The trees were planted in spring 1934.

\begin{tabular}{|c|c|c|c|c|c|c|}
\hline \multirow{2}{*}{\multicolumn{2}{|c|}{$\begin{array}{l}\text { Lajike ja puun } \mathrm{N}: \mathrm{o} \\
\text { Variety and no. of tree }\end{array}$}} & \multicolumn{5}{|c|}{$\begin{array}{l}\text { Kokonaissadot vuosina. } \mathrm{Kg} \text {. } \\
\text { Total crops in the years. } \mathrm{Kg}\end{array}$} \\
\hline & & $1934-39$ & $1940-44$ & $1945-49$ & $1950-52$ & $1934-52$ \\
\hline \multirow[t]{2}{*}{ Sokeri-Miron } & VI:3 & 4.7 & 44.5 & 157.9 & 183.4 & 390.5 \\
\hline & VI:4 & 6.4 & 53.9 & 256.2 & 104.7 & 421.2 \\
\hline \multirow[t]{4}{*}{ I-ruutu } & VII:3 & 3.6 & 56.8 & 183.5 & 162.3 & 406.2 \\
\hline & VII:4 & 2.4 & 46.0 & 198.2 & 203.8 & 450.4 \\
\hline & II: 7 & 4.2 & 29.0 & 171.0 & 201.3 & 405.5 \\
\hline & II: 8 & 1.0 & 52.1 & 220.7 & 80.1 & 353.9 \\
\hline \multirow[t]{4}{*}{ III-ruutu } & III: 7 & 7.2 & 34.1 & 192.9 & 230.0 & 464.2 \\
\hline & III: 8 & 3.6 & 18.3 & 141.1 & 61.4 & 224.4 \\
\hline & IV:11 & 4.7 & 66.0 & 89.6 & 113.9 & 274.2 \\
\hline & IV:12 & 1.7 & 36.9 & 223.8 & 252.6 & 515.0 \\
\hline \multirow[t]{3}{*}{ III-ruutu } & $\mathrm{V}: 11$ & 3.5 & 25.4 & 151.7 & 231.8 & 412.4 \\
\hline & $\mathrm{V}: 12$ & 2.1 & 8.4 & 134.2 & 71.7 & 216.4 \\
\hline & $\mathrm{XI}: 15$ & 4.9 & 33.0 & 88.7 & 125.7 & 252.2 \\
\hline IV-ruutu & $\mathrm{XI}: 16$ & 0.6 & 55.2 & 83.0 & 159.7 & 298.5 \\
\hline \multirow[t]{2}{*}{ Lepaan meloni } & II:3 & 3.0 & 15.0 & 34.1 & 52.3 & 104.4 \\
\hline & II: 4 & 3.2 & 22.7 & 77.4 & 44.0 & 147.3 \\
\hline \multirow[t]{4}{*}{ I-ruutu } & III:3 & 0.5 & 15.7 & 64.0 & 54.3 & 134.5 \\
\hline & III: 4 & 2.1 & 20.6 & 64.1 & 45.7 & 132.5 \\
\hline & VIII: 7 & 0.2 & 9.6 & 75.9 & 63.2 & 148.9 \\
\hline & VIII: 8 & 5.2 & 28.3 & 99.9 & 61.0 & 194.4 \\
\hline \multirow[t]{4}{*}{ II-ruutu } & IX: 7 & 5.7 & 20.7 & 75.0 & 60.2 & 161.6 \\
\hline & IX: 8 & 4.0 & 4.2 & 23.6 & 50.1 & 81.9 \\
\hline & $\mathrm{X}: 12$ & 1.2 & 13.8 & 36.0 & 33.3 & 84.3 \\
\hline & $\mathrm{X}: 11$ & 3.0 & 13.7 & 64.5 & 59.5 & 140.7 \\
\hline \multirow[t]{4}{*}{ III-ruutu } & XI:11 & 7.4 & 10.9 & 37.3 & 30.0 & 85.6 \\
\hline & $\mathrm{XI}: 12$ & 0.7 & 9.7 & 82.5 & 56.1 & 149.0 \\
\hline & VI:15 & 5.2 & 34.3 & 84.6 & 78.4 & 202.5 \\
\hline & VI: 16 & 2.5 & 5.4 & 20.2 & 60.0 & 88.1 \\
\hline \multirow[t]{2}{*}{ IV-ruutu } & VII:15 & 4.2 & 21.5 & 28.1 & 45.3 & 99.1 \\
\hline & VII: 16 & 1.2 & 7.5 & 25.0 & 44.5 & 78.2 \\
\hline
\end{tabular}

Sokeri Miron. Ensimmäisen Sokeri Miron-ruudun (piirros 1) neljän puun kokonaissadot ovat muodostuneet varsin tasaisiksi puiden ollessa 19-vuotiaita (390 _ 406 - $421-450 \mathrm{~kg}$ ). Toisessa ruudussa ovat kolmen puun sadot nousseet melko lähelle toisiaan, mutta sensijaan neljäs on jäänyt runsaasti muita heikommaksi $(224-354-405-464 \mathrm{~kg})$. Kolmannessa ruudussa on kokonaissatojen vaihtelu jo suurempi $(216-274-412-515 \mathrm{~kg})$. Kaksi viimeistä Sokeri Miron-puuta, jotka kasvavat etäämpänä muiden koeruutujen puista, ovat antaneet kokonaissadoiksi 257 ja $297 \mathrm{~kg}$. Parhaimman ja heikoimman puuyksilön satoerot ovat eri Sokeri Miron-ruuduissa olleet $1.1,2.1,2.4$ ja 1.2 kertaiset. 
Neljä puuta käsittävien koeruutujen kokonaissadot poikkeavat hyvin vähän toisistaan:

$$
\begin{aligned}
& \text { I-ruatu II-ruutu III-ruutu } \\
& \text { Kokonaissato } \ldots \ldots \ldots . \quad 1667 \mathrm{~kg} \quad 1447 \mathrm{~kg} \quad 1417 \mathrm{~kg}
\end{aligned}
$$

Sokeri Miron-puiden ollessa nuorempia ovat niiden satotulokset vaihdelleet huomattavasti enemmän. 11-vuotiaina ovat esimerkiksi koeruutu III:ssa puiden satoerot suuret. Parhaimman puun sato $(70.6 \mathrm{~kg})$ on tällöin ollut 7 kertaa suurempi heikoimman puun antamaa satoa $(10.5 \mathrm{~kg})$. Seuraavan viisivuotiskauden $(12-16 \mathrm{v}$.) aikana ovat edellämainittujen kahden puun kokonaissadot nousseet jo hyvin lähelle toisiaan (160 ja $145 \mathrm{~kg}$ ) satojen eron ollessa enää 1.1 kertainen. Puiden antamat satomäärät ovat saattaneet myös vuosittain vaihdella runsaasti, mutta myöhemmässä vaiheessa ovat vaihtelut taas tasaantuneet. Tästä on esimerkkinä taulukko 1, josta selviävät Sokeri Miron-ruutu I:n neljän puun vuosittaiset satotulokset.

Lepaan Meloni. Lepaan Meloni-puut ovat istutuksesta lähtien säilyneet täysin vaurioitumatta. Lajikkeen ominaissatoisuus on huomattavasti Sokeri Miron'in satoisuutta heikompi. Ensimmäisen Lepaan Meloni-ruudun puut (piirros 2) ovat 19-vuotiaina antaneet melko samansuuruiset kokonaissadot $(104-132-134-$ $147 \mathrm{~kg}$ ), mutta muissa ruuduissa on vaihtelu jo jonkin verran suurempaa. Parhaimman ja heikoimman yksilön satojen ero on eri koeruuduissa 1.4, 2.4, 1.8 ja 2.6 kertainen. 11 vuoteen mennessä istutuksesta lukien ovat satojen vaihtelut tälläkin lajikkeella olleet suuret, mutta myöhemmin ne ovat tasaantuneet. Eri koeruutujen kokonaissadot 19 vuoden aikana muodostuvat verraten tasaisiksi:

$$
\begin{array}{cccc}
\text { I } & \text { II } & \text { III } & \text { IV } \\
519 \mathrm{~kg} & 587 \mathrm{~kg} & 459 \mathrm{~kg} & 468 \mathrm{~kg}
\end{array}
$$

Snygg. Snygg-lajikkeesta (piirros 3) on satotulokset laskettu 15-vuotisista puista ja puita on kaikkiaan $12 \mathrm{kpl}$. Jo 10 ensimmäisen vuoden kokonaissadot, joita pylväiden tummat alaosat esittävät, ovat muodostuneet erittäin yhdenmukaisiksi $(75,84,88,114,150,74,79,71,83,70,46$ ja $65 \mathrm{~kg})$. Yhdenmukaisempiin satoihin tuskin voidaan päästä mitään suvutonta perusrunkoa käyttäen. 15-vuotiaiden Snygg-puiden kokonaissadot ovat vaihdelleet jo jonkinverran enemmän. Kuitenkin

Piirros 3. Siemenperusrungoille vartettujen Snygg-puiden kokonaissadot v. 1934-48. Pylvään tumma alaosa esittää puun kokonaissatoa 10-vuotiaana (v. 1934 43) ja vaalea yläosa satoa seuraavalta viisivuotiskaudelta (v. 1944-48). Puut on istutettu 1934 keväällä.

Fig. 3. Total crops of the apple variety Snygg upon seedling stocks during the years 1934-48. In the diagram the dark lower parts represent the total crops of the trees for the first 10 years (during the years $1934-43$ ) and the upper parts crops of the following five-year period (during the years $1944-48)$.

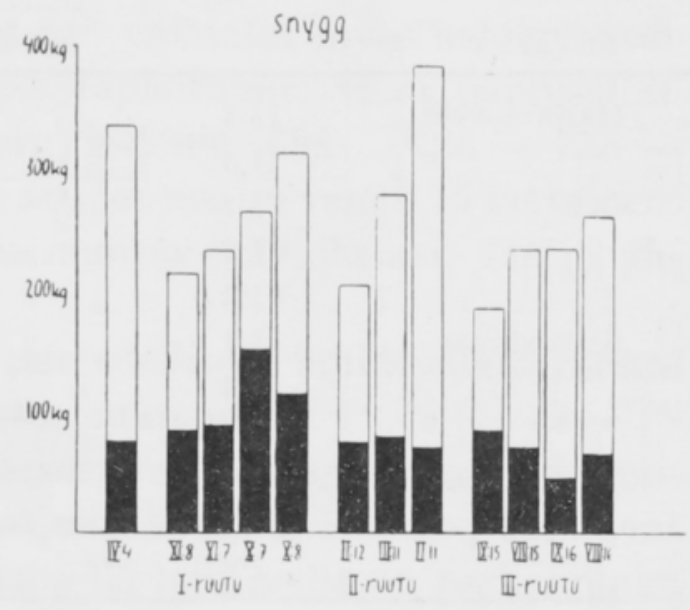


Taulukko 3. Snygg-puiden kokonaissadot eri ikäjaksoina. Puut on istutettu 1934 keväällä.

Table 3. Total crops of Snygg apple trees. The trees were planted in spring 1934.

\begin{tabular}{|c|c|c|c|c|}
\hline \multirow[t]{2}{*}{$\begin{array}{l}\text { Puun No. } \\
\text { No. of tree }\end{array}$} & & \multicolumn{3}{|c|}{$\begin{array}{l}\text { Kokonaissadot vuosina } \\
\text { Total crops in the years. } \mathrm{Kg}\end{array}$} \\
\hline & & $1934-43$ & $1944-48$ & $1934 \quad 48$ \\
\hline \multirow[t]{12}{*}{ Snygg } & IV:4 & 74.8 & 258.6 & 333.4 \\
\hline & $X: 7$ & 150.3 & 112.4 & 262.7 \\
\hline & $\mathrm{X}: 8$ & 113.8 & 197.4 & 311.2 \\
\hline & XI: 7 & 88.4 & 142.7 & 231.1 \\
\hline & XI:8 & 84.1 & 127.9 & 212.0 \\
\hline & II:11 & 70.8 & 313.0 & 383.8 \\
\hline & II: 12 & 74.0 & 129.5 & 203.5 \\
\hline & III:11 & 79.1 & 198.2 & 277.3 \\
\hline & VIII: 15 & 70.2 & 161.8 & 232.0 \\
\hline & VIII: 16 & 65.3 & 195.3 & 260.6 \\
\hline & IX: 15 & 83.0 & 101.0 & 184.0 \\
\hline & IX: 16 & 45.6 & 187.1 & 232.7 \\
\hline
\end{tabular}

ovat puiden sadot ensimmäisessä $(212-231-263-311 \mathrm{~kg})$ ja kolmannessa $(184-232-233-261 \mathrm{~kg})$ koeruudussa edelleen tasaisia. Parhaimman ja heikoimman yksilön satojen erot ovat eri koeruuduissa 1.5, 1.9 ja 1.4 kertaiset.

Edellä mainittujen koepuiden lisäksi esitettäköön vielä eräiden siemenperusrungoille vartettujen Harlamovski-, Sävstaholm-, Kaneli-, Viurilan ananas- ja Sariola-puiden (piirros 4) satoja 21 vuoden iän saavutettuaan. Nämä puut ovat kasvaneet puutarhaosaston hiekkamaan hedelmätarhassa samaan lajikkeeseen kuu-

Tallukko 4. Harlamovski-, Sävstaholm- ja Viurilan ananas-puiden kokonaissadot eri ikäjaksoina. Puut istutettu keväällä 1932 .

Table 4. Total crops of Harlamovsky, Sävstaholm and Viurilan ananas trees. The trees were planted in spring 1932.

Lajike ja puun N:o

Variety and no. of tree
Kokonaissadot vuosina. Kg.

Total crops in the years. $\mathrm{Kg}$.

\begin{tabular}{|c|c|c|c|c|c|}
\hline & & \\
\hline & & $1932-42$ & $1943-47$ & $1948-52$ & $1932-52$. \\
\hline \multirow[t]{5}{*}{ Harlamovski } & II:4 & 210.3 & 204.1 & 281.4 & 695.8 \\
\hline & II:5 & 152.4 & 215.9 & 430.9 & 799.2 \\
\hline & VI: 1 & 146.0 & 227.3 & 413.0 & 786.3 \\
\hline & $\mathrm{VI}: 2$ & 136.3 & 212.0 & 409.5 & 757.8 \\
\hline & VI:3 & 120.3 & 202.5 & 405.1 & 727.9 \\
\hline \multirow[t]{3}{*}{ Sävstaholm } & II:1 & 71.8 & 197.7 & 494.7 & 763.4 \\
\hline & II:3 & 47.5 & 123.4 & 273.2 & 444.1 \\
\hline & VI:4 & 27.4 & 106.9 & 407.0 & 541.3 \\
\hline \multirow[t]{3}{*}{ Viurilan ananas } & $\mathrm{I}: 4$ & 59.3 & 64.1 & 154.5 & 277.9 \\
\hline & $\mathrm{I}: 5$ & 38.2 & 52.7 & 119.8 & 210.7 \\
\hline & $\mathrm{I}: 6$ & 38.5 & 44.8 & 164.5 & 247.8 \\
\hline
\end{tabular}




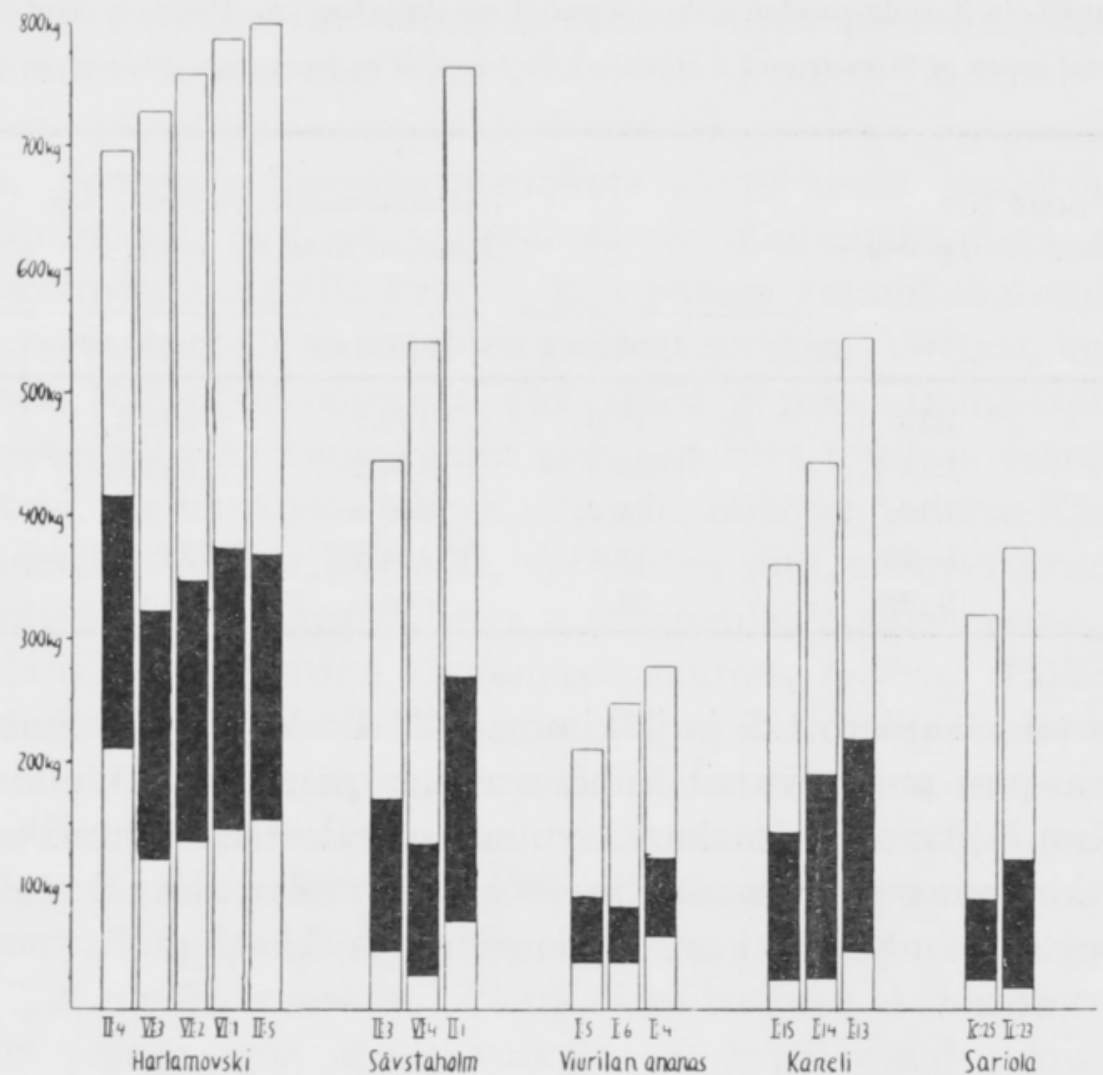

Piirros 4. Siemenperusrungoille vartettujen Harlamovski-, Sävstaholm- ja Viurilan ananas-puiden kokonaissadot v. 1932 - 52. Pylvään vaalea alaosa esittää puun kokonaissatoa v. 1932 —42, tumma keskusta satoa v. 1943-47 ja vaalea huippu satoa v. 1948 -52. Puut on istutettu 1932 keväällä. V. 1932 syksyllä istutettujen Kaneli- ja Sariola-puiden sadot ovat vastaavasti vuosilta 1933-43, $1944-48$ ja $1949-52$.

Fig. 4. Total crops of the apple varieties Harlamovky, Sävstaholm and Viurilan ananas during the years 1932-52. In the diagram the lower parts represent the total crops during the years 1932_42, the dark middle parts that in 1943-47 and the uppermost parts the total crops during the last five-year period. Similarly the total crops of Kaneli and Sariola trees are shown for the years $1933-43,1944-48$ and $1949-52$.

luvien puiden kasvaessa lähekkäin. Puiden kasvupaikalla ei ole havaittavissa mitään oleellisia eroavaisuuksia maanlaadussa.

Harlamovski-puiden kokonaissadot ovat 21 vuoteen mennessä nousseet huomattavan korkeiksi, parhaimpien miltei $800 \mathrm{~kg}$ :an. Kun satoluvut ovat muodostuneet näin korkeiksi, olisi odotettavissa, että satojen vaihtelut myös kehittyisivät silmiinpistävän suuriksi. Näin ei kuitenkaan ole tapahtunut, vaan päinvastoin sadot ovat muodostuneet erittäin samanlaisiksi eri yksilöillä $(696-728-758-$ 786 - $799 \mathrm{~kg}$ ). Parhaimman ja heikoimman puun satojen ero on vain 1.15 kertainen. Puiden kokonaissadot ovat pysyneet myös nuoremmissa ikävaiheissa, 11- ja 16vuotisina, hyvin tasaisina toisiinsa nähden.

Sävstaholm-puilla ovat vaihtelut suurempia kuin edellisellä lajikkeella parhaimman puun sadon ollessa 1.7 kertaa heikoimman satoa suurempi.

Kolmen 20-vuotiaan Kaneli-puun kokonaissadoissa on vastaava ero 1.5 kertainen. Kaksi 20-vuotiasta Sariola- ja kolme 21-vuotiasta Viurilan ananas-puuta ovat antaneet taas hyvin tasaiset kokonaissadot. Edellisellä lajikkeella on parhaimman 
Taulukko 5. Kaneli- ja Sariola-puiden kokonaissadot eri ikäjaksoina. Puut on istutettu 1932 syksyllä.

Table 5. Total crops of Kaneli and Sariola apple trees. The trees were planted in autumn 1932.

\begin{tabular}{|c|c|c|c|c|c|}
\hline \multirow{2}{*}{\multicolumn{2}{|c|}{$\begin{array}{l}\text { Lajike ja puun N:o } \\
\text { Variety and no. of the tree }\end{array}$}} & \multicolumn{4}{|c|}{$\begin{array}{l}\text { Kokonaissadot vuosina. } \mathrm{Kg} \text {. } \\
\text { Total crops in the years. } \mathrm{Kg} \text {. }\end{array}$} \\
\hline & & $1933-43$ & $1944-48$ & $1949-52$ & $1933-52$ \\
\hline \multirow[t]{3}{*}{ Kaneli } & I: 13 & 47.0 & 172.7 & 324.9 & 544.6 \\
\hline & $\mathrm{I}: 14$ & 25.5 & 164.2 & 253.7 & 443.4 \\
\hline & I:15 & 24.2 & 119.8 & 217.5 & 361.5 \\
\hline \multirow[t]{2}{*}{ Sariola } & Ic: 23 & 18.4 & 104.2 & 252.6 & 375.2 \\
\hline & Ic:25 & 24.1 & 66.0 & 230.9 & 321.0 \\
\hline
\end{tabular}

ja heikomman puun satoero 1.2- ja jälkimmäisellä 1.3-kertainen. Sadoltaan heikoin Viurilan ananas-puu on kasvanut kahden muun puun välissä etäisyyden ollessa vain $4 \mathrm{~m}$. Kun lajike on voimakaskasvuinen muodostaen suhteellisen leveän latvuston, on keskimmäinen puu luonnollisesti kärsinyt tilan ahtaudesta myöhemmällä iällään. Sen molemmin puolin kasvaneilla saman lajikkeen puilla sensijaan on ollut riittävästi kasvutilaa.

\section{Yhteenveto}

Vaikka edellä käsitelty aineisto on suppea, voidaan sen perusteella todeta, että samaa alkuperää olevat kotimaiset siemenperusrungot eivät ole aiheuttaneet huomattavampia yksilöllisiä vaihteluja näillä perusrungoilla kasvavien saman lajikkeen puiden satoihin. Useimmat puut ovat päinvastoin antaneet erittäin yhdenmukaisia kokonaissatoja pitemmän ajanjakson kuluttua tarkasteltaessa.

Myöhään satoikään tulevilla lajikkeilla, kuten Sokeri Miron ja Lepaan Meloni, ovat kokonaissatojen vaihtelut olleet suuremmat puiden ollessa nuoria (6-11vuotisia), mutta puiden tultua varsinaiseen satoikään, ovat niiden kokonaissatojen väliset erot alkaneet nopeasti tasoittua. Sensijaan kysymyksen ollessa aikaisin satoikään tulevista lajikkeista, kuten Snygg ja Harlamovski, ovat saman lajikkeen siemenperusrungoilla kasvaneet puut jo varhaisemmalla iällä (10-11 vuotiaina) antaneet toisiinsa nähden verraten samansuuruisia kokonaissatoja.

Kuten Meurmanin tutkimuksista (7) on jo käynyt ilmi, ovat saman lajikkeen siemenperusrungoilla kasvaneiden puiden vuosittaiset sadot saattaneet vaihdella runsaasti. Tästä huolimatta ovat puiden kokonaissadot pysyneet melko yhdenmukaisina. Vuosittainen vaihtelu johtuu luonnollisesti puiden jaksottaissatoisuudesta. Edellä käsitellyssä aineistossa voidaan osoittaa hyvin vähän sellaisia saman lajikkeen puuyksilöitä, jotka ovat vuosi vuodelta antaneet runsaampia satoja kuin muut. Eri puuyksilöiden satojen suhteet ovat usein vaihdelleet siten, että puu, joka jossakin ikävaiheessaan on jäänyt kokonaissadossa toisesta saman lajikkeen puusta jälkeen, on †aas myöhemmässä vaiheessa tavoittanut ja usein ohittanutkin tämän. 
HatTonin (2) mukaan voi saman lajikkeen siemenperusrungoilla kasvaneista puista parhaimmissa tapauksissa vain 70 tai $80 \%$ olla kohtalaisen verrannollisia satoisuuden y.m. ominaisuuksiensa suhteen muiden puiden osorttaessa aina suurempia vaihteluja. Sensijaan klooniperusrunkoja käytettäessä ei tällaisia vaihteluja ilmenisi. Valitettavasti ei tässä yhteydessä ole ollut mahdollista verrata edellä esitettyjen siemenperusrungoilla kasvaneiden puiden antamia satotuloksia samanikäisten klooniperusrungoille vartettujen puiden satoihin. Viittaan kuitenkin niihin koetuloksiin joita Malling-kloonirunkoja käyttäen on maassamme saatu (8). Näissä kokeissa kloonirungoilla kasvaneet puut ovat antaneet toisiinsa verrattuna erittäin vaihtelevia satoja. Se suuri yksilöllinen vaihtelu, mikä on todettu East Malling'issa siemenperusrungoilla kasvaneilla puilla, voi johtua siitä, että perusrunkojen kasvattamiseen on käytetty myös triploidisten omenapuulajikkeıden siemeniä. Triploidisia omenapuulajikkeita viljellään Englannissa suuressa määrin. Tällaista alkuperää olevat perusrungot eivät, kuten KEMmeR (5) osoittaa, ole läheskään niin yhdenmukaisia kuin diploidista, valittua alkuperää olevat siementaimet.

Eräänä varsin merkittävänä etuna tiettyjen M-kloonirunkojen käytöstä on korostettu sitä, että niille vartetut omenapuut alkavat jo nuorena antaa satoa, kun sensijaan siemenperusrungorlle vartettujen puiden satoikään tuloa pidetään näihin verrattuna paljon myöhäisempänä. Tämä ei kuitenkaan ole niinkään selvästi osoitettavissa, sillä perusrungon ohella vaikuttavat myös muut tekijät omenapuun satoiän alkamiseen. Erityisesti on tällöin erilaisilla leikkausmenetelmillä varsin suuri merkitys. Soveltamalla perusrungon kasvunvoimakkuuteen sopivaa leikkaustapaa antavat voimakaskasvuisille siemenperusrungoillekin vartetut puut jo nuorina suuria satoja (8).

Mainittakoon vielä, että kotimaisille siemenperusrungoille vartettujen puiden ilmastollinen kestävyys on maamme olosuhteissa osoittautunut selvästi paremmaksi kuin M-klooniperusrungoilla kasvaneiden puiden (11). Viimeksi mainittujen perusrunkojen heikko kestävyys tekeekin niiden käytön maassamme varsin rajoitetuksi

\author{
KIRJALLISUUTTA
}

(1) Gourley, J. H. - Howlett, F. S. 1947. Modern Fruit Production, p. 482. New York.

(2) Hatron, R. G. 1923. The influence of root stock upon the tree fruits. The Fruit-Grower, Fruiterer, Florist \& Market Gardener. London.

(3) - 1928. The influence of different root stocks upon the vigour and productivity of the variety budded or grafted thereon. J. of Pomology and Hortic. Sci. 6, p. 1-28.

(4) —— 1935. Apple rootstock studies. Effect of layered stocks upon the vigour and cropping of certain scions. Ibid. 13, p. $293-350$.

(5) Kemmer, E. 1950. Die Kernobstunterlagen. Institut für Obstbau. Merkblatt 4, 5. Aufl. 20 pp. Berlin 1950

(6) Meurman, O. 1945. Omenapuiden vaihtelevasta satoisuudesta. Puutarhavilj. Liiton Julk. 45, p. $1-8$.

(7) — - 1946. Numerotietoja omenapuiden sadoista. Ibid. 54, p. 3-6.

(8) —- 1953. Trials with "Spindelbusch" apple trees in Finland. Acta. Agr. Scand. 3, p. 292-306 
(9) Palmer, R. C. 1950. Dwarf apple trees. Ref. from Hortic. Abstr. 20 no 566.

(10) Southwick, L. \& Shaw, J. K. 1939. Further notes on the Malling clonal stocks in relation to Mc Intosh and Wealthy. Proceedings of the Amer. Soc. for Hortic. Sci. 36, p. 133-137.

(11) Sӓкӧ, J. 1952. Kestävämpiä perusrunkoja omenapuillemme. Maatalous ja Koetoiminta 6, p. $110-119$.

(12) Uppshai.L, W. H. 1947. Malling apple rootstocks (at Vineland, Ont.). Ref. from Hortic. Abstr. 17, no 584 .

S U M M A R Y:

THE INFLUENCE OF SEEDLING ROOTSTOCKS UPON THE CROPPING OF APPLE TREES

$$
\text { JААKКО SÄKÖ }
$$

Agricultural Research Centre, Department of Horticulture, Piikkiö.

At the Department of Horticulture annotations on the yearly crop of a number of different apple varieties. In this paper are given the crop records of certain trees, grafted upon Finnish seedling rootstocks of known origin for periods of 15-21 years from plantingtime onwards. The general management of all these trees, such as pruning, manuring, etc., has been uniform all the time.

Although the material available was rather small, it was established that the seedling rootstocks used have not had any marked influence upon the productivity of the individual trees of one and the same variety. On the contrary, most of the trees have had very uniform total crops if the periods taken into consideration have been sufficiently long.

The apple varieties which start to crop rather late, such as Sugar-Miron or Lepaan meloni, may show rather large individual variations during the first years of cropping (the period from 6 to 11 years). Later, when the trees reach full cropping age, the variation begins to diminish. Some early cropping varieties, such as Snygg and Harlamovsky, on the other hand, show a striking uniformity in the yields of the individual trees even during the first period.

In general, it may be stated that despite the existence of much variation in the annual cropping of the individual trees, the records of total crops from the same trees for periods of several years remain fairly uniform, as has already been pointed out.

Unfortunately it was not possible to make direct comparisons between the trees considered here and others grafted upon clonal rootstocks. Reference may be made, however, to Meurman's (1953) paper on the yield records of certain apple trees upon Malling rootstocks grown in Finland. The individual trees in trials reported in that paper revealed a very high variability in yield, in spite of the hereditary uniformity of the clonal stocks used.

The hardiness of the trees grafted upon Finnish seedling stocks appears to be distinctly better than that of trees upon clonal Malling stocks in our conditions. Apparently this is one of the main reasons why relatively great variation exists between the cropping records of individual trees grafted on clonal stocks when compared with the greater uniformity of cropping present in trees grafted upon Finnish seedling rootstocks. 